\title{
DIRECTORY OF THE ENGINEERING ALUMNI OF THE UNIVERSITY OF IOWA
}

(I903)

[NOTE-Prior to 1892 the degree of Civil Engineer or Electrical Engineer was conferred on the completion of the four years' course. Beginning with the class of 1892 , the degree conferred has been the Bachelor of Science in these courses.]

Apple, Beaumont, B. S. in E. E., '96. With Des Moines National Bank, Des Moines, Iowa.

Bailey, Arthur, B. S. in E. E., '96. Banking Business, Charles City, Iowa.

Bailey, Chas. H., B. S. in C. E., '95.

Barber, N. B., B. S. in C. E., '99. Assistant Engineer C.

R. I. \& P. Ry. Colorado Springs, Colo.

Beard, Wm. F., B. S. in C. E., 'oo. Assistant Engineer C.

B. \& Q. Ry., Burlington, Iowa.

Berry hill, R. B., C. E., '86.

Blazier, Herbert E., C. E., '82. Williamsburg, Iowa.

Blood, Henry S., C. E., '9o, LL. B.,'93. County Surveyor and Attorney at Law, Bottineau, North Dakota.

Bowman, E. C., B. S. in C. E., '99. With W. D. Lovell, Consulting Engineer, Minneapolis, Minn.

Bremner, Geo. H., C. E., '83. Engineer Illinois Lines C. B. \& Q. R. R. Co., Room 67 C., B. \& Q. offices, 209 Adams St., Chicago, Ill.

Bremner, Wm. H., C. E., '9r, LL. B., '95. City Solicitor, Des Moines, Iowa.

Brown, Alden H., C. E., '9I. Mine Engineer and Operator, Jamestown, Colo.

Brown, Elwyn N., C. E., '83. 
Brown, Wm. D., C. E., '78. Of the firm of Brown \& Anderson, Attorneys at Law, Onawa, Iowa.

Bryant, Walter, C. E. '86. 78 E. ist North St., Salt Lake City, Utah.

Buckman, O. H., C. E., '76. City Engineer and Superintendent of Streets, City of Napa, Napa Co., California.

Burrier, Emmett Francis, 'O2. Deceased.

Burton, Chas. H., C. E., '89, LL. B., '95. Attorney at Law, St. Louis, Mo.

Call, Roy G., 'O3, B. S. in E. E., New Jersey Electric Co., Newark, N. J.

Cannon, Robt. M., B. S. in C. E., '92. Consulting Civil and Mining Engineer, Colorado Springs, Colo.

Carlson, Ernst Emil, 'o3. With Bridge Department L. S. \& M. S. Ry. Co., Cleveland, O.

Cassidy, L. L., C. E., '78. Assistant Treasurer New England Loan and Trust Co., 34 Nassau St., New York.

Chamberlain, Fred H., C. E., 'go. Deceased.

Choate, Rufus Clark. Assistant Engineer, Piedmont Construction Co., Mattoon, Ill.

Childs, O. W., '89., Mem. Am. Soc. C. E. Chief Engineer Stupp Bros. Bridge and Iron Co., St. Louis, Mo. Address, 230r South 7th St., St. Louis, Mo.

Clark, Chas. H. Jr., C. E., '84. I900 Arlington Ave., Des Moines, Iowa.

Clements, M. F., B. S. in C. E., '99. Assistant Engineer C. R. I. \& P. Ry. Co., Chicago, Ill.

Cox, Arthur J., C. E., '9r, LL. B., '95. Civil Engineer, Iowa City, Iowa, Member of Iowa Engineering Co.

Crane, Will E., C. E., '82, A. M., '85, Mem. Am. Soc. C. E. Consulting Engineer, 220 W. 57th St., New York. Crellin, E. W., C. E., '9o. President Des Moines Bridge and Iron Works, Des Moines, Iowa. 
Currier, Albert Moore, 'o3. Assistant Engineer C. B. \& Q. Ry. Co., Galesburg, Ill.

Darling, Wiм. A., C. E., '87. Manufacturer, Davenport, Iowa. Address, Rock Island, Ill.

Dey, Curtis T., B. S. in C. E., '94. C. T. Dey \& Co., Iowa City, Iowa.

Dey, Marvin H., C. E., '87. Manager East Chicago Bridge \& Iron Co., Chicago, Ill.

Dupuis, Newton, C. E., '87. Member of firm of W. M. Walsh \& Co., I7I and I73 Randolph St., Chicago, Ill.

Fatherson, T. W., B. S., in C. E., 'oo. Assistant Engineer, C., R. I. \& P. Ry., Cedar Rapids, Iowa.

Gableman, Fred B., B. S. in C. E., '96. Chief Draftsman for Tuttle \& Pike, Civil Engineers, 60o Baird Building, South and Wyandotte Sts., Kansas City, Mo.

Gale, Absolom, C. E., '84. State Senator. Banker, Mason City, Iowa.

Gardner, John R., B. S. in C. E., '94. Principal of Schools at Hawkeye and County Surveyor of Fayette County, Hawkeye, Iowa.

Greene, R. A., C. E., '85. Representative from Madison County and City Engineer of Winterset, Iowa. Address, East Perry, Iowa.

Hagler, Elisha Manon. With Missouri Bridge \& Iron Co., St. Louis, Mo.

Hall, Chas. S., C. E., '8o. Engineer in charge of the W. \& St. P. Division of the C. \& N. W. Ry. Headquarters at Winona, Minn.

Hartman, R. T., B. S. in C. E., '96, M. S., '98. Chief Draftsman for Des Moines Bridge \& Iron Co., Des Moines, Ia. Hastings, Frank A., C. E., '9r. With American Bridge Co., Pittsburg, Pa. Address, No. 67 So. Dithridge St.

Hayler, Geo. Rex, '92, Engineer, St. Louis Terminal. St. Louis, Mo. 
Helmick, Chas. W., C. E., '82. Civil and Mining Engineer, U. S. Deputy Mineral Surveyor, III7 Eighth Ave., Helena, Montana.

Hewitт, C. E., B. S. in C. E., '97. In General Engineering Office, C., B. \& Q. Ry., at Chicago, Ill.

Hickenlooper, Thos. W., B. S. in C. E., 'or. With American Bridge Co., Minneapolis, Minn.

Howe, Joseph H., C. E., '9o. Supervisor Bridge and Building Department, Nebraska Division, U. P. R. R., Omaha, Neb.

Hubbard, F. R., B. S. in C. E., '96. With Scherzer Rolling Lift Bridge Co., Monadnock Building, Chicago, Ill.

Huntington, W. Spencer, B. S. in C. E., '95. Chief Engineer, St. Paul Foundry Co., St. Paul, Minn.

Hunter, L. A., B. S. in C. E., 'oo. Deceased.

Hutchinson, Zel H., B. S. in C. E., '95. Muscatine Lumber Co., Muscatine, Iowa.

Jensen, Frank T., B. S. in C. E., 'or. Banker, Dysart, Iowa.

Johnson, Maro, B. S. in C. E., '98. Assistant Engineer, Ill. Cent. Ry. Address, Iowa City, Iowa.

Knapp, Leo, B. S. in C. E., 'oo. With C. \& N. W. Ry. Co., Eagle Grove, Iowa.

Koza, Frank J., B. S. in E. E., '9o. Government Draftsman, Rock Island, Ill.

Lambert, B. J., B. S. in C. E., 'or. Instructor in Civil Engineering, University of Iowa.

Lee, Ray P., B. S. in E. E., '94. Mfg. Agt. Street Railroad Supplies, Electrical Building, W. Jackson Boulevard, Chicago, Ill.

Lichту, C. A., C. E. '9o. Superintendent of Bridges and Buildings, Wisconsin Division of the C. \& N. W. Ry., Fond du Lac, Wis.

Lovell, Frederick W., B. S. in C. E., '94. Chief Engi- 
neer for McMyler Manufacturing Co., Manufacturers of Dock Equipment Machinery, Cleveland, Ohio.

Lovell, Walter D., C. E., '9i, Mem. Am. Soc. C. E.

Consulting Engineer; Specialty, Municipal Engineering. Equitable Building, Des Moines, Iowa.

Magowan, Chas. S., C. E., '84, A. M. '87. Professor Municipal and Sanitary Engineering, University of Iowa, Iowa City, Iowa.

Manhard, Edward, 'O2. Draftsman with Des Moines Bridge and Iron Co., Des Moines, Iowa.

Marsh, Richard Dana, 'O2. With W. D. Lovell, Des Moines, Iowa.

McVay, Albert Dennis. With Ill. Cent. Ry. Co., Chicago, Ill.

Meggers, F. H. Jr., B. S. in C. E., 'oo. Assistant Engineer C. R. I. \& P. Ry., Des Moines, Iowa.

Miller, Geo. W., C. E., '79. Of the firm of Miller \& Hoyt, Manchester, Iowa.

Miller, F. J., B. S. in C. E., '99. Chief Engineer Columbia River and Northern Ry. Co., Lyle, Wash.

Morehouse, Harry L., B. S. in C. E., '95. Salt Lake City, Utah.

Mount, Wм. E., C. E., '87. General Engineering Practice, Lordsburg, California.

Musser, R. Drew, C. E., '88. With Pine Tree Lumber Co., Little Falls, Minn.

Newell, Geo. W., B. S. in C. E., '96. Draftsman for Des Moines Bridge and Iron Co., Des Moines, Iowa.

Noble, Glenn S., B. S. in C. E., '94. Civil and Mechanical Engineer, 705 Garden City Block, Randolph and Fifth Avenue, Chicago, Ill.

Noble, Ralph E., B. S. in E. E., '94. Chief Engineer of the

Morgan-Gardner Electric Co., Chicago, Ill.

North, Howard M., C. E., '92. 
Ogle, Alfred N., C. E., '83. Deceased.

Page, Chas. Prue. With Des Moines Bridge \& Iron Co.

Polley, John F., C. E., ' 76 . Division Engineer and Draftsman for the Montana Railroad Co., Helena, Montana.

Powell, Wm. P., B. S. in C. E., '95. Cedar Rapids, Iowa. Powers, Milton J., C. E., '9r. Banking Business, Flagstaff, Arizona.

Rall, Chas. R., C. E., '86. Assistant Secretary and General Sales Agent, Best Manufacturing Co., Pittsburg, Pa.

RAy, Fred, B. S. in C. E., '92. Topographer, Mississippi River Commission. I I I 5 Fullerton Building, St. Louis, Mo.

Reeder, Geo. K., C. E., '8r. Craig, Montana.

Remley, Hubert, C. E., '9o. With W. D. Lovell, Minneapolis, Minn.

Rice, Elton, C. E., '9r. Chief Engineer, Massillon Bridge Co., I 8 McLain St., Massillon, Ohio.

Rice, S. E., B. S. in C. E., 'or. With Illinois Steel Co., Chicago, Ill.

Robinson, A. Dean, C. E., '8o. Civil Engineer with the Chicala Water Co. Address, Rialto, San Bernardino County, California.

Roвish, A. A., B. S. in C. E., 'oo. Sumner, Iowa.

SAylor, E. C., B. S. in E. E., '98. Draftsman, Colorado Midland Ry., Colorado Springs, Colo.

Schlatter, Geo. R., C. E., '85. Bellevue, Iowa.

Schultz, J. O., B. S. in C. E., '97. Lumber, Irving, Dallas Co., Texas.

Sears, J. H., B. S. in C. E., '96. With Forest City Steel and Iron Works, Cleveland, Ohio.

Shimeк, Bohumil, C. E., '83. Professor of Physiological Botany and Curator of the Herbarium, University of Iowa, Iowa City, Iowa. 
Smith, C. H. W., B. S. in C. E., '93. With Corps of Engineers, U.S. A. Address, care of U. S. Engineer Office, Grand Rapids, Mich.

Smith, Chas. H., B. S. in C. E., 'or. With W. D. Lovell, Des Moines, Iowa.

Spencer, John C., C. E., '9r. American Bridge Co., Pittsburg, Pa., 5 Ist St. Offices.

Stover, Samuel Kirkwood, B. S. in E. E., Newark, N. J.

Sweney, Marshall Charles, 'O3. Assistant Engineer, Ill. Cent. Ry., Ripley, Tenn.

Van Arsdol, C. C., C. E., '76. Constructing Engineer for the Northern Pacific Ry., Lewiston, Idaho.

VAn Veer, SAm'L., B. S. in C. E., '92. Superintendent of Erection for Benj. Hyde Construction Co.

Vincent, Ed. F., C. E., '84.

Wallberg, Emil A., C. E., '9i. Bridge Engineer, Bell Telephone Building, Montreal Canada.

Weeks, G. D., B. S. in C. E., 'or. Chief Draftsman, St. L. \& S. F. Ry., Springfield, Mo.

White, F. G., B. S. in C. E., '99. Assistant City Engineer, Salt Lake City, Utah.

Wilkin, Frank S., B. S. in C. E., '97. With Cincinnati, Buffalo \& Chicago, Bluffton, Ind.

Willis, B. D., B. S. in E. E., '96. Designing Engineer with Stromberg-Carlson Telephone Manufacturing Co., 70-80 Washington Boulevard, Chicago.

Woodward, Gideon W., C. E., '86. Ahmedabad, India. Wolfe, John D., M. D., C. E., '86. Mt. Vernon, Iowa. Woolston, Frank, B. S. in C. E., '94. Denison, Iowa. Young, Oscar R., C. E., '86. Deceased. 